four hours as shown by the figures of the second column in Table V.

TABLE VII.-MEAN RESUltS FOR DAILY EXCRETION.

Volume excreted $\ldots \ldots \ldots \ldots \ldots \ldots \ldots \ldots$ I 67.00 cc.

Total reduction, equivalent to $\ldots \ldots \ldots \ldots .3 .3 \mathrm{I}$ grams $\mathrm{C}_{6} \mathrm{H}_{12} \mathrm{O}_{6}$.

Uric acid and creatinin reduction equiva-

lent to $\ldots \ldots \ldots \ldots \ldots \ldots \ldots \ldots \ldots$

Remaining reduction equivalent to......

Amount of ammonia.................

Amount of urea (mean of gas method and

Liebig, corr. $\ldots \ldots \ldots \ldots \ldots \ldots \ldots \ldots$

Amount of creatinin ..................

Amount of uric acid..................

$\begin{array}{ll}\mathrm{I} .54 \quad \text { " } & \text { " } \\ \mathrm{I} .77 & \text { " } \\ 0.703 & \text { gram. }\end{array}$

29.75 grams.

I. 624

0.799 gram.

The urines examined in the above experiments were all normal and represent the excretion from average meat and vegetable diet. In a following paper I will give results obtained from urines of consistent vegetarians, noting the same relations. Most of the experimental work detailed above was done by Mr. Frank Wright, assistant in the laboratory of physiological chemistry, and Mr. Charles Ericson, to whom my thanks are due.

NORTHWESTERN UNIVERSITY,

Chicago, April 24, 1900.

\title{
AN EXAMINATION OF BROWN AND TAYLOR'S OFFICIAL METHOD OF IDENTIFYING BUTTER.
}

BY JOHX A. HUMMEL.

Received March 7, 1900.

THE recent great increase in the production of renovated butter, due probably to the improvements in the method of its manufacture and the prevailing high price of creamery butter, has necessitated, in several states, the enactment of laws regulating its sale. Since the enactment of these laws there has been some discussion as to reliable methods for its identification. The fact that the chemical properties and the proximate composition of samples examined are entirely within the range of normal butter, has directed attention to its physical properties more particularly its behavior with polarized light. As is already wellknown, in the manufacture of renovated butter, the butter-fat is melted and then cooled rather rapidly in a stream of cold water. This melting and rapid cooling induces a semicrystallization of 
the fat. It was thought that this fact might be taken advantage of and would at least deserve some study. For the experiments carried on in this laboratory fifteen samples of renovated butter secured from factories in St. Paul, Minneapolis and Duluth were used; as many samples of undoubted normal butter from Minnesota creameries and dairies were also examined. The preparations for the microscopic examination were mi de by simply placing a small bit of the butter on a glass slide and pressing it into a thin film with a cover-glass. The preparation was then immediately examined with a polarizing microscope giving a magnification of 120 to 150 diameters. A selenite plate was placed between the slide and the lower nicol. In every case the normal butters gave with the selenite which was used a uniformly blue colored field, showing the entire absence of fat crystals. The renovated butters on the other hand gave a blue field mottled with yellow; this mottled appearance varied slightly in intensity but was very marked and distinctive in every case. The accompanying photomicrographs are from representative preparations and are believed to be fair averages. In making these photomicrographs the selenite was not used, the thin film of butter being simply placed between crossed nicols. The source of light was a 16 candle-power incandescent electric light, and an exposure of fifteen minutes was necessary for the normal butter, eleven minutes for the renovated butter, and eight minutes for the oleomargarine, using plates of medium rapidity.

The writer is well aware of the severe criticism directed against the method proposed by Dr. J. Campbell Brown, and later by Dr. Taylor, for identifying adulterated butter by means of the microscope and polarized light, yet he has found a microscopic examination of great value, and believes it to be one of the best methods for the identification of renovated butter, as found upon the Minnesota markets at least. In the course of work in this laboratory 247 samples of butter have been subjected to a microscopic examination as outlined above and out of this number 58 showed conclusive evidence of having been melted and cooled as in the process of renovating. A majority of those samples which could be traced to the manufacturers were admitted as being renovated and some fines have been imposed. 


$$
8
$$





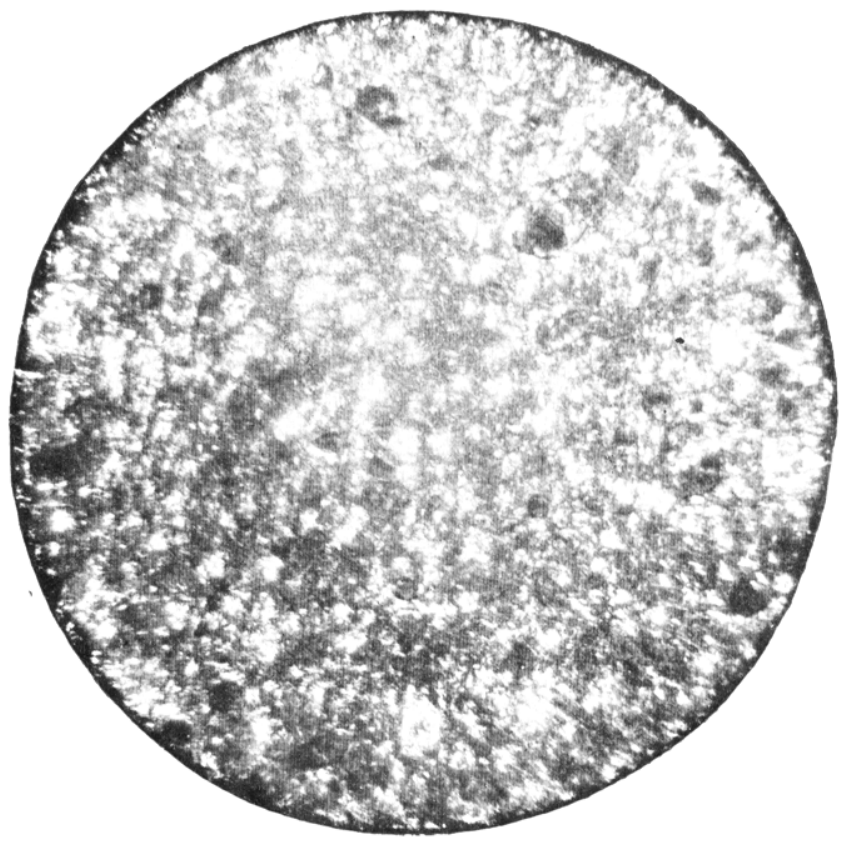

Fig. 3.-Oleomargarine. 

In the examination of these samples the greatest reliance was placed in every case on the microscopic appearance, though other tests were aiso used.

I,ABoratory of the Minnesota State Dairy and Food Commission.

[FROM THE DEPARTMENT OF PHYSIOLOGICAL CHEMISTRY, PATHOLOGICAL INSTITUTE OF THE N. Y. STATE HOSPITALS.]

\section{ON THE PREPARATION OF NUCLEIC ACIDS. ${ }^{1}$}

BY P. A. LEVENE.

Received April :4, 1900.

T $\mathrm{HE}$ various modifications of Altman's and Kossel's methods of obtaining nucleic acid, which have appeared during the last year clearly demonstrate two facts: first, that the old methods were unsatisfactory; and secondly, that a thorough knowledge of the nucleo compounds is of ever-increasing importance to all investigators in the field of the chemistry of the cell.

All the new methods published in recent years are based on two properties of the nucleic acids; namely, their solubility in acetates and their resistance to dilute alkalies on heating. Both properties were observed only by the authors of the new methods. The improvement recently advocated by Schmiedeberg was based on the idea of removing (by means of copper salts) the proteid material which combines with the nucleic acids, to form the nucleo-compounds occurring in cells and tissues.

One of the properties of the nucleic acids described by the more recent investigators, namely their resistance to heating with alkalies, stands in contradiction to the observations of the older workers. Thus Miescher considered it requisite that the material which was being treated for nuclein should be kept at a very low temperature during every phase of its preparation. Kossel has succeeded in decomposing the ordinary nucleic acid of the thymus into thymic acid by heating it in water on the water-bath.

Neuman, advocating the heating method with alkalies, states that by this method more than one acid is generally obtained. From the fact that different proportions of the acids vary with the duration of heating, he draws the conclusion that the three acids are modifications of the one occurring in the tissue.

1 Read before the New York Section of the American Chemical Society, April 6, rgoo. 